\title{
Perbandingan Indeks Androgen Bebas dan Lemak Viseral Pasien Sindrom Ovarium Polikistik di Poliklinik Aster RSUP Dr. Hasan Sadikin Bandung sebelum dan setelah Pemberian Terapi Metformin
}

\author{
Imelda Rosmaida Siagian, Mulyanusa Amarullah Ritonga, Maringan D.L.Tobing, \\ M. Rizkar Arev Sukarsa \\ Departemen Obstetri dan Ginekologi Fakultas Kedokteran Universitas Padjadjaran/ \\ RSUP Hasan Sadikin Bandung \\ Korepondensi : Imelda Rosmaida Siagian, Email: meldaobg13@gmail.com
}

\begin{abstract}
Abstrak
Tujuan: Terdapat 50-70\% kasus sindrom ovarium polikistik yang berkaitan dengan adanya resistensi insulin. Peran agen sensitisasi insulin seperti metformin diharapkan dapat memperbaiki kondisi lemak dan testosteron bebas yang tinggi sehingga memperbaiki gejala klinis pasien dengan sindrom ovarium polikistik. Penelitian ini bertujuan mengetahui perbedaan indeks androgen bebas (sebagai representasi kadar testosteron) dan lemak viseral pasien sindrom ovarium polikistik sebelum dan sesudah diberi pengobatan metformin.

Metode : Populasi penelitian didapatkan dari data penelitian DLBS (Dexa Laboratories of Biomolecular Sciences) 3233 yaitu 29 kasus wanita sindrom ovarium polikistik yang datang untuk berobat di Klinik Aster RSUP Dr. Hasan Sadikin Bandung periode Januari 2013 - Desember 2017, dengan menggunakan metode experimental design dengan pendekatan one group pretest-posttest design. Pengambilan sampel penelitian dilakukan secara purposing sampling yang diambil secara retrospektif pada data sekunder yang terdapat dalam rekam medik.

Hasil: Didapatkan rata-rata indeks androgen bebas sebelum pemberian terapi metformin $2.67 \pm 0.43$ dan sesudah pemberian terapi $1.88 \pm 0.37$. Rata-rata kadar lemak visceral sebelum pemberian terapi metformin $10.27 \pm 2.589 \%$ dan sesudah pemberian terapi $8.00 \pm 1.488 \%$.

Kesimpulan: Sehingga disimpulkan terdapat perbedaan signifikan kadar indeks androgen bebas (p:0.008) dan lemak visceral (p:0,0001) pada pasien sindrom ovarium polikistik sebelum dan sesudah pemberian terapi metformin.
\end{abstract}

Kata kunci : Sindrom ovarian polikistik, testosterone, lemak visceral, metformin

\section{Comparasion of free Androgen Index and Viseral Fat in Polycystic Ovary Syndrome Patients in Aster Polyclinic Dr. Hasan Sadikin Bandung Before and After Giving Metformin Therapy}

\footnotetext{
Abstract

Objective: There are 50-70\% of cases of polycystic ovary syndrome associated with insulin resistance. The role of insulin sensitizing agents such as metformin is expected to improve the condition of high fat and free testosteron, thereby improving the clinical symptoms of patients with polycystic ovary syndrome. This study aims to determine differences in free androgen index (represent the value of free testosteron) and visceral fat levels of polycystic ovary syndrome patients before and after being given metformin treatment.

Method: The study population was obtained from DLBS (Dexa Laboratories of Biomolecular Sciences) 3233 research data, namely 29 cases of polycystic ovary syndrome women who came for treatment at the Aster Clinic Dr. Hasan Sadikin Bandung from January 2013 - December 2017, using the experimental design method with the one group pretest-posttest design approach. Sampling was done by purposing sampling taken retrospectively on secondary data contained in the medical record.

Result : The average free androgen index levels were obtained before the administration of metformin therapy $2.67 \pm 0.43$ and after the administration of therapy $1.88 \pm 0.37$ Average visceral fat levels before administration of metformin therapy $10.27 \pm 2.589 \%$ and after administration of $8.00 \pm 1,488 \%$.

Conclusion: It was concluded that there were significant differences in free androgen index (p: 0.008) and visceral fat (p: 0.0001) in patients with polycystic ovary syndrome before and after metformin therapy.

Keyword : Polycystic ovary syndrome, free androgen index, viseral fat, metformin
} 


\section{Pendahuluan}

Sindrom Ovarium Polikistik adalah kelainan endokrin yang sangat umum terjadi pada wanita dalam masa reproduksi. Sindrom ini paling banyak diperdebatkan dan menimbulkan pendapat-pendapat yang kontroversial dalam bidang Ginekologi Endokrinologi dan Reproduksi. ${ }^{1}$ Pada tahun 2003 diRotterdam, European Society of human reproduction and Embryology (ESHRE) dan American Society for Reproductive Medicine (ASRM), menyatakan bahwa sindrom ovarium polikistik adalah kelainan endokrin dengan ciri adanya dua dari tiga kriteria berupa (1) kelainan ovulasi kronik seperti oligo atau anovulasi, (2) gambaran klinis atau biokimia adanya hiperandrogenism dan (3) adanya ovarium polikistik (dengan telah menyingkirkan penyebab lainnya). ${ }^{2}$ Kriteria lain yang juga digunakan dalam mendiagnosis sindrom ovarium polikistik adalah kriteria dari National Institutes of Health. Sindrom ovarium polikistik menurut National Institutes of Health adalah adanya anouvulasi kronis dengan tanda klinis atau biokimia adanya hiperandrogen. ${ }^{3}$

Sindrom ovarium polikistik adalah salah satu kelainan endokrin yang paling sering dijumpai pada perempuan usia reproduksi.Sindrom ovarium polikistik juga mempengaruhi kesuburan. ${ }^{4}$ Saat ini, angka kejadian sindrom ovarium polikistik sering kali dihitung berdasarkan kriteria diagnosis, berdasarkan kriteria National Institutes of Health, sindrom ovarium polikistik mempegaruhi 4-8 \% wanita usia reproduksi (24-28 tahun). ${ }^{5}$

Interaksi dari beberapa faktor genetik dan lingkungan menyebabkan adanya fenotip heterogen, klinik dan biokimia pada kasus sindrom ovarium polikistik. ${ }^{7}$ Sindrom ovarium polikistik juga meningkatkan risiko resistensi insulin, diabetes tipe 2 , obesitas dan penyakit kardiovaskular. ${ }^{8}$ Terdapat 50$70 \%$ kasus sindrom ovarium polikistik yang berkaitan dengan adanya resistensi insulin. ${ }^{9}$

Penyebab utama dari sindrom ovarium polikistik belum diketahui, maka pengobatan ditujukan langsung untuk mengobati gejala yang ada. Tujuan pengobatan pada kasus sindrom ovarium polikistik adalah memperbaiki anovulasi, mencegah aksi androgen pada jaringan target dan menurunkan resistensi insulin. Kondisi hiperandogen pada sindrom ovarium polikistik dapat dideteksi secara biokimia dengan mengukur kadar testosteron bebas. Testosteron dapat digunakan sebagai alat diagnostik dan juga penilaian keberhasilan terapi. ${ }^{10,11}$ Hirsutism adalah penanda adanya kondisi hiperandrogen. Hirsutism terdapat pada hampir $70 \%$ pasien sindrom ovarium polikistik. Fokus utama dalam pengobatan kondisi hiperandrogen adalah penurunkan kadar testosteron bebas. Penghitungan kadar testosterone bebas dapat dilakukan dengan melalui nilai total testosterone dan SHBG yang dikenal dengan indeks androgen bebas. ${ }^{12}$

Kondisi gangguan metabolik pada kasus sindrom ovarium polikistik, dapat dikurangi melalui pengobatan dengan metformin, namun kondisi utama pada penyakit sindrom ovarium polikistik, bukanlah gangguan metabolik melainkan adanya kondisi hiperandrogen. Kondisi gangguan metabolik pada pasien sindrom ovarium polikistik berhubungan secara signifikan dengan kondisi lemak viseral. ${ }^{13,14}$ Kondisi peningkatan BMI dan lemak viseral juga dihubungkan dengan kondisi tingginya resistensi insulin tetapi pengaruhnya terhadap menstruasi, hirsutism dan hiperandrogen belum dapat dijelaskan. ${ }^{12}$ Wilcox menjelaskan, lemak viseral diketahui memiliki korelasi positif dengan kadar testosteron dalam tubuh. ${ }^{15}$

Resistensi insulin pada otot dan jaringan lemak meningkatkan asam lemak bebas dalam plasma dan konsentrasi insulin, merangsang sintesis dan sekresi VLDL (very-low-density lipoprotein) di hati yang mengakibatkan hipertrigliseridemia. Peran agen sensitisasi 
insulin seperti metformin diharapkan dapat memperbaiki kondisi lemak dan testosteron bebas yang tinggi sehingga memperbaiki gejala klinis pasien dengan sindrom ovarium polikistik.

Beberapa pengamat gagal menjelaskan perubahan biokimia yang disebabkan oleh metformin, ${ }^{11}$ sehingga dibutuhkan penelitian lebih lanjut untuk menilai pengobatan dengan metformin pada pasien dengan sindrom ovarium polikistik dalam pengaruhnya terhadap testosteron, dan secara tidak langsung terhadap lemak viseral. Penelitian ini mengharapkan terdapat perbedaan signifikan pada kadar testosteron dan lemak viseral pasien sindrom ovarium polikistik sebelum dan sesudah diberi pengobatan metformin. Data-data yang diperoleh dari penelitian diharapkan dapat digunakan sebagai data dasar penelitian lebih lanjut mengenai standar keberhasilan pengobatan dan pengobatan yang tepat pada pasien sindrom ovarium polikistik.

\section{Metode}

Populasi penelitian didapatkan dari data penelitian DLBS 3233 yaitu semua kasus wanita sindrom ovarium polikistik yang datang untuk berobat di klinik Aster RSUP Dr. Hasan Sadikin Bandung periode Januari 2013 - Desember 2017. Subjek penelitian adalah semua kasus wanita sindrom ovarium polikistik yang datang untuk berobat di klinik Aster Rumah Sakit Umum Pendidikan Dr. Hasan Sadikin Bandung periode Januari 2013- Desember 2017 yang diberikan terapi metformin dan diketahui memiliki kondisi dengan resistensi insulin dengan fungsi liver dan ginjal dalam batas normal

Pasien sindrom ovarium polikistik yang sebelumnya pernah mendapatkan terapi metformin selama lebih dari 6 bulan dan yang tidak melanjutkan pengobatan (drop out) dikeluarkan dari subjek penelitian

Ukuran sampel sesuai dengan tujuan penelitian yaitu merupakan penelitian analitik kategorik komperatif numerik berpasangan. Maka penentuan besar sampel, dilakukan berdasarkan perhitungan statistik dengan menetapkan taraf kepercayaan 95\% dan kuasa uji (power test) 95\%. Dengan demikian jumlah sampel minimal adalah 14 orang, kemudian ditambah dengan $10 \%$ kemungkinan pengeluaran sampel sehingga jumlah sampel adalah $14+1,4=15,4 \approx 16$ orang.

Metode penelitian menggunakan desain penelitian eksperimen dengan metode pendekatan desain pretest-posttest satu group. Penelitian eksperimen adalah penelitian yang dilakukan untuk mengetahui akibat yang ditimbulkan dari suatu perlakuan yang diberikan secara sengaja oleh peneliti.

Sedangkan pendekatan desain pretestposttest satu group adalah desain ini terdapat pre test sebelum diberi perlakuan . Dengan demikian hasil perlakuan dapat diketahui lebih akurat, karena dapat membandingkan dengan keadaan sebelum diberi perlakuan

Dilihat dari hubungan antar variabelnya, penelitian ini merupakan penelitian kausal atau sebab akibat, yaitu penelitian yang diadakan untuk menjelaskan hubungan antar variabel, variabel yang satu menyebabkan atau menentukan nilai variabel yang lain. Pengambilan sampel penelitian dilakukan secara purposive sampling yang diambil secara retrospektif pada data sekunder yang terdapat dalam rekam medik.

Purposive sampling yaitu salah satu teknik sampling non random sampling dimana peneliti menentukan pengambilan sampel dengan cara menetapkan ciri-ciri khusus yang sesuai dengan tujuan penelitian sehingga diharapkan dapat menjawab permasalahan penelitian.

Berdasarkan penjelasan purposive sampling tersebut, ada dua hal yang sangat penting dalam menggunakan teknik sampling tersebut, yaitu non random sampling dan menetapkan ciri khusus 
sesuai tujuan penelitian. Variabel bebas yang digunakan dalam penelitian ini adalah Metformin. Variabel terikat yang digunakan dalam penelitian ini adalah indeks androgen bebas dan lemak viseral

Hasil

Tabel 1 Karakterikstik Sample Penelitian

\begin{tabular}{cccc}
\hline & Variabel & $\begin{array}{c}\text { Jumlah } \\
\text { sample }\end{array}$ & Rerata \\
\hline Usia & 25 tahun & 1 & \\
& $25-35$ tahun & 21 & 32,45 \\
& $>35$ tahun & 6 & \\
& $>40$ tahun & 1 & \\
BMI & & & \\
& $<18.5$ & $(-)$ & \\
$18.5-24.9$ & 6 & \\
$25-29.9$ & 18 & 27,93 \\
& $30-34.9$ & 1 & \\
& $\geq 35$ & 4 & \\
Siklus Mestruasi & & \\
$\quad<24$ hari & 1 & \\
$24-35$ hari & 8 & 51,59 \\
$\quad>35$ hari & 20 & \\
Skor Ferriman & & \\
Gallwey & & \\
$<8$ & 16 & \\
8 8-15 & 12 & 7,03 \\
$>15$ & $(-)$ & \\
\hline
\end{tabular}

Tabel 1 menjelaskan karakteristik pasien yang diteliti. Usia terbanyak adalah antara 25-35 tahun dengan rata-rata 32 tahun. BMI pasien terbanyak adalah dalam kategori obesitas dengan rata- rata BMI 27.93. Siklus menstruasi memanjang dengan rata-rata 51 hari dan Skro ferryman gallwey 7, tidak banyak yang mempunyai keluhan hirtutism.

Tabel 2, menjelaskan perbandingan antara indeks androgen bebas pada kelompok I dan II. Pada kelompok I, Untuk indeks androgen bebas memiliki rata-rata sebesar $2.67 \pm 0.43$. Pada kelompok II, Untuk indeks androgen bebas memiliki rata-rata sebesar $1.88 \pm 0.37$.Untuk analisis data Numerik ini diuji dengan menggunakan uji $\mathrm{T}$ berpasangan apabila data berdistribusi normal serta alternative uji Wilcoxon apabila data tidak berdistribusi normal yaitu indeks androgen bebas. Hasil uji statistika pada kelompok penelitian diatas diperoleh informasi nilai $\mathrm{P}$ pada variable indeks androgen bebas lebih kecil dari 0.05 (nilai $\mathrm{P}<0.05$ ) yang berarti signifikan atau bermakna secara statistik dengan demikian dapat dijelaskan bahwa terdapat perbedaan rerata yang signifikan secara statistik antara variable indeks androgen bebas pada kelompok I dan II.

Tabel 2 Perbandingan antara Indeks Androgen Bebas pada Kelompok I dan II.

\begin{tabular}{ccc}
\hline \multirow{2}{*}{ Variabel } & \multicolumn{2}{c}{ Kelompok Fiksasi } \\
\cline { 2 - 3 } & $\begin{array}{c}\text { I } \\
\mathrm{N}=29\end{array}$ & $\mathrm{~N}=\mathbf{2 9}$ \\
\end{tabular}

Indeks

androgen

$0.008 * *$

bebas

Mean \pm Std $\quad 2.67 \pm 0.43 \quad 1.88 \pm 0.37$

$\begin{array}{lll}\text { Median } & 2.22 & 1.40\end{array}$

Range

(min-max)

$0.31-11.68 \quad 0.09-8.41$

Keterangan : Untuk data numerik nilai $p$ diuji dengan uji $\mathrm{T}$ berpasangan apabila data berdsitribusi normal dengan alternatif uji Wilcoxon apabila data tidak berdistribusi normal..Nilai kemaknaan berdasarkan nilai $\mathrm{p}<0,05$.Tanda* menunjukkan nilai $\mathrm{p}<0,05$ artinya signifkan atau bermakna secara statistik.

Tabel 3, menjelaskan perbandingan antara Viseral Fat $(\%)$ pada kelompok I dan II. Pada kelompok I, Untuk Viseral Fat memiliki rata-rata sebesar $10.27 \pm 2.589$.

Pada kelompok II, Untuk Viseral Fat (\%) memiliki rata-rata sebesar $8.00 \pm 1.488$.

Untuk analisis data Numerik ini diuji dengan menggunakan uji $\mathrm{T}$ berpasangan apabila data berdistribusi normal serta alternative uji Wilcoxon apabila data tidak berdistribusi normal yaitu Viseral Fat(\%). 
Tabel 3 Perbandingan Antara Viseral Fat (\%) pada Kelompok I dan II.

\begin{tabular}{lccc}
\hline & \multicolumn{2}{c}{ Kelompok Fiksasi } & \\
\cline { 2 - 3 } Variabel & $\mathbf{I}$ & $\mathbf{I I}$ & Nilai P \\
& $\mathbf{N}=\mathbf{2 9}$ & $\mathbf{N}=\mathbf{2 9}$ & \\
\hline Viseral & & & $0.0001^{* *}$ \\
Fat (\%) & & & \\
Mean \pm Std & $10.27 \pm 2.589$ & $8.00 \pm 1.488$ & \\
Median & 9.00 & 8.00 & \\
$\begin{array}{l}\text { Range } \\
\text { (min-max) }\end{array}$ & $7.00-16.00$ & $5.00-11.00$ & \\
\hline
\end{tabular}

Keterangan : Untuk data numerik nilai $\mathrm{p}$ diuji dengan uji $\mathrm{T}$ berpasangan apabila data berdsitribusi normal dengan alternatif uji Wilcoxon apabila data tidak berdistribusi normal..Nilai kemaknaan berdasarkan nilai $\mathrm{p}<0,05$.Tanda* menunjukkan nilai $\mathrm{p}<0,05$ artinya signifkan atau bermakna secara statistik.

Hasil uji statistika pada kelompok penelitian diatas diperoleh informasi nilai $\mathrm{P}$ pada variable Viseral Fat $(\%)$ lebih kecil dari 0.05 (nilai $\mathrm{P}<0.05$ ) yang berarti signifikan atau bermakna secara statistik dengan demikian dapat dijelaskan bahwa terdapat perbedaan rerata yang signifikan secara statistik antara variable Viseral Fat pada kelompok I dan II.

\section{Pembahasan}

Dari data yang didapatkan, dapat disimpulkan terdapat perbedaan yang signifikan indeks androgen bebas sebelum dan sesudah pemberian terapi metformin pada pasien sindrom ovarium polikistik. Insulin dapat secara langsung merangsang sitokrom P450c17a ovarium, menghasilkan peningkatan 17-a hidroksilase. Ini akan menyebabkan peningkatan produksi androstenedion, yang kemudian dikonversi menjadi testosteron oleh enzim $17 \mathrm{~b}$ reduktase dan menghasilkan tingkat testosteron bebas yang lebih tinggi. Dengan adanya metformin, sebagai agen sensitisasi insulin, diharapkan kadar insulin dalam darah menurun karna banyak digunakan didalam sel, sehingga diharapkan dapat memperbaiki kondisi testosteron bebas (yang dilihat dari indeks androgen bebas) yang tinggi sehingga memperbaiki gejala klinis pasien dengan sindrom ovarium polikistik.Dari data yang didapatkan, dapat disimpulkan terdapat perbedaan yang signifikan lemak viseral (\%) sebelum dan sesudah pemberian terapi metformin pada pasien sindrom ovarium polikistik. Hal ini mendukung beberapa penelitian yang mengatakan bahwa resistensi insulin pada pasien sindrom ovarium polikistik berhubungan dengan kadar adinopectin, yaitu hormon yang disekresikan dari sel adiposa yang berfungsi dalam metabolisme lemak dan glukosa. Dengan pemberian obat metformin yang merupakan agen sensitisasi insulin, maka diharapkan metabolisme lemak dan gliukosa membaik sehingga kadar lemak viseral juga akan menurun. Resistensi insulin memiliki peran dalam patogenesis kasus sindrom ovarium polikistik. Kedepannya diharapkan dapat dibuktikan adanya bahwa dengan adanya penurunan kadar lemak viseral pada pasien sindrom ovarian polikistik, menjadi tolak ukur dalam keberhasilan terapi metformin.

Dari penelitian ini dapat disimpulkan terdapat perbedaan yang signifikan indeks androgen bebas dan lemak visceral (\%) sebelum dan sesudah pemberian metformin.

\section{Daftar Pustaka}

1. Hestiantoro A, Wiweke B, Maidarti Mi, Fernando D, Puspita CG. Sindrom Ovarium Polikistik. In: Hestianto A, Natadisastra M, Wiweko B, Sumapraja $\mathrm{K}$, Harzif A kemal, editors. Current Updates on Polycystic ovary syndrome Endometriosis Adenomyosis. Jakarta: Sagung Seto; 2013. p. 3-69.

2. Lizneva D, Suturina L, Walker W, Brakta S, Gavrilova-Jordan L, Azziz R. Criteria, prevalence, and phenotypes of 
polycystic ovary syndrome. Fertil Steril. 2016;106(1):6-15.

3. Mohammad MB, Seghinsara A majdi. Polycystic Ovary Syndrome (PCOS), Diagnostic Criteria, and AMH. Asian Pacific J Cancer Prev. 2017;18(27):1721.

4. Schorge JO, Schaffer JI, Halvorson LM, Hoffman BL, Bradshaw KD, Cunningham FG. Williams Gynecology. Schorge JO, Schaffer JI, Halvorson LM, Hoffman BL, Bradshaw KD, Cunningham FG, editors. 2008. 779-806 p.

5. Sirmans SM, Pate KA. Epidemiologydiagnosis-and-management-ofpolycystic-ovary-s. Dove Press J [Internet]. 2014;1-13.

6. Ding T, Hardiman PJ, Petersen I, Wang F-F, Qu F, Baio G. The prevalence of polycystic ovary syndrome in reproductive-aged women of different ethnicity: a systematic review and metaanalysis. Oncotarget. 2017;8(56):963518.

7. Xita N, Georgiou I, Tsatsoulis A. The genetic basis of polycystic ovary syndrome. Eur J Endocrinol. 2002 Dec;147(6):717-25.

8. Diamanti-Kandarakis E, Kandarakis $\mathrm{H}$, Legro RS. The role of genes and environment in the etiology of PCOS. Endocrine. 2006 Aug;30(1):19-26.

9. DeUgarte CM, Bartolucci AA, Azziz R. Prevalence of insulin resistance in the polycystic ovary syndrome using the homeostasis model assessment. Fertil Steril. 2005 May;83(5):1454-60.

10. Berek JS. Berek \& Novak's gynecology. 15 th ed. Berek JS, Novak E, editors. 2012. 1542-1558 p.

11. Singh B, Panda S, Nanda R. Effect of Metformin on Hormonal and Biochemical Profile in PCOS Before and After Therapy. Ind $\mathrm{J}$ Clin Biochem. 2010;25(February 2006):367-70.

12. Fauser BCJM, Tarlatzis BC, Rebar RW,
Legro RS, Balen AH, Lobo R, et al. Consensus on women's health aspects of polycystic ovary syndrome (PCOS): The Amsterdam ESHRE/ASRM-Sponsored 3rd PCOS Consensus Workshop Group. Fertil Steril. 2012;97(1):28-38.e25.

13. Lord J, Thomas R, Fox B, Acharya U, Wilkin T. The central issue? Visceral fat mass is a good marker of insulin resistance and metabolic disturbance in women with polycystic ovary syndrome. BJOG. 2006 Oct;113(10):1203-9.

14. Karabulut A, Yaylali GF, Demirlenk S, Sevket O, Acun A. Evaluation of body fat distribution in PCOS and its association with carotid atherosclerosis and insulin resistance. Gynecol Endocrinol. 2012 Feb;28(2):111-4.

15. Wilcox T, Hirshkowitz A. Testosterone and Visceral Fat in Midlife Women: The Study of Women's Health Across the Nation (SWAN) Fat Patterning Study. NIH Public Access. 2015;85(0 1):1-27. 